Volume 4 Number 2 December 2020

\title{
Effectiveness of Using Gamification Media for Mastering Indonesian affiliates in Thailand Students at Universitas Islam Darul ‘Ulum Lamongan
}

Bisarul Ihsan, Yessy Soniatin

Universitas Islam Darul 'Ulum Lamongan

bisarulihsan@unisda.ac.id,yessysoniatin@unisda.ac.id

\begin{abstract}
This study aims to see the response of students from Thailand at the Universitas Islam Darul 'Ulum Lamongan to the use of gamification media, as well as to see the effectiveness of the acquisition of Indonesian affixation by Thai students using gamification media. This research uses descriptive method, with observation and test data collection techniques. The results of this study are the highest response to statement 1 of $92.3 \%$, namely in the very interesting category, the highest response to the second statement of $100 \%$, namely in category 4 , the highest response to statement 3 of $61.5 \%$ namely in category 4 , the highest response to statement 4 th is $80.8 \%$ in category 4 , and the highest response is to statement 5 of $61.5 \%$ in category 4 .The effectiveness result in cycle I reaches 391 words with Indonesian affixes, then in cycle II it increases by 196 so that in cycle II data is obtained as large as 587 words with affixes.
\end{abstract}

Keywords: gamification, Indonesian affixes, students from Thailand.

\begin{tabular}{ll}
\hline Article History & Received : August $7^{\text {th }} 2020$ \\
& Revision : October $11^{\text {th }} 2020$ \\
& Publication : Dec $30^{\text {th }} 2020$ \\
\hline
\end{tabular}

\section{INTRODUCTION}

The development of learning media, especially in mobile learning, has progressed rapidly, this is very helpful for teachers and students both in terms of time effectiveness and learning variations so that it is not boring. Various online and offline based learning media services are offered with the aim of facilitating the teaching and learning process. Such rapid technological developments can now be enjoyed by various groups and all fields. One of the studies (Vermana \& Zuzano, 2018) shows an increase in student learning outcomes by using the flipped Classroom learning model.

Many academics have conducted research that focuses on the effectiveness and outcomes of learning. At the college level, students are generally more likely to spend more time playing games. Therefore, an idea emerged in this study to combine learning with games to increase student motivation.

Students from Thailand, especially students who are taking undergraduate (S-1) education at private universities, especially at the Universitas Islam Darul 
'ulum Lamongan, are students who are included in the category of second language learners (B2). Their first language (B1) is Thai (Thailand). Meanwhile, when in Indonesia they will learn Indonesian as their second language (B2) to interact with the environment.

The scope of Indonesian language learning includes four aspects, namely reading, listening, speaking and writing. Of the four skills, writing skills are considered as difficult skills. This is because writing skills require mastery of grammar disciplines.

The introduction of morphemes in this case is that affixation of B2 students is very necessary. This is because Indonesian is an agglutinative language (an affix to a root word that results in a change in meaning or usage) which results in one basic word when it gets affixes it will experience a change in meaning.

Research conducted by Ihsan (2017), shows that there are errors in writing Indonesian written by students from Thailand who are currently studying at the Islamic University of Darul 'Ulum Lamongan. These mistakes are in the form of the use of interference sentences, reduplication errors, deleting errors, and errors in writing affixes. Therefore, researchers in the study used gamification media in order to help Thai students master the Indonesian language at the level of affixation morphemes. This is because a student cannot be separated from writing skills activities to complete the final project (Thesis).

Affixes in Indonesian are the addition of letters or sounds either in the form of prefixes, infixes or suffixes (Amrulloh, 2017). One word that gets an affix will change the meaning of the word. Based on these references, language errors often occur due to interference in the first language. The linguistic structure between languages is never eliminated for most B2 learners (Tarigan \& Tarigan, 2011).

In a study (Sambung et al., 2017) with the title Gamification-Based Mobile Learning Development for Japanese Vocabulary Mastery Class X SMAN 1 Garum resulted in a study that interactive multimedia was declared effective in the learning process, with details on students who met the KKM $(\geq 750)$ obtained a percentage of $93 \%$ after the use of interactive multimedia. In another study, namely research by (Wastari \& Sagoro, 2018), with the research title Application of Gamification-Based Cooperative Learning Model to Improve Learning Outcomes of Adjustment Journal Material in Class X Accounting G Students of Muhammadiyah 1 Yogyakarta Vocational School. Resulting in an increase in student learning, the pre-test average value of $10.71 \%$, then in the post test cycle I increased to $42.86 \%$, and in the post test cycle II was $82.14 \%$.

The quality of learning is always related to the use of optimal, interesting, and innovative learning methods / media to achieve success in learning objectives. Gamification media is a learning medium that uses thinking and games to solve problems in a fun way. The application of gamifiation media is an effort to increase 
students' motivation to learn and also provide a memorable experience. By combining game / game elements with learning elements, the learning process will be more interesting.

Based on several studies conducted using gamification, it is hoped that this study will also be able to facilitate the effectiveness of mastery of Indonesian affixation for Thai students at Darul 'Ulum Islam University in Lamongan. Gamification media is the application of techniques and strategies from a game to a learning context that aims to solve a problem (Sambung et al., 2017).

\section{METHOD}

The method used in this research is descriptive method, which is a research method that describes the object of research in accordance with existing conditions without changing it. In this case, the researcher explains the effectiveness of using gamification media in the mastery of Indonesian affixes to Thai students. This research was conducted at PTS Universitas Islam Darul 'Ulum Lamongan. While the data analysis technique used in this research is through three stages, namely: data reduction, data presentation, and drawing conclusions. The data analysis technique of the respondents' results has 4 answer choices according to the question content. The scoring rate is based on the attractiveness of the gamification product for each respondent. The assessment score for respondents for gamification can be seen in the following table.

Table 1. Student Responses

\begin{tabular}{c|l} 
Score & Choice Answers Attractive Gamification \\
\hline 4 & Very Interesting \\
\hline 3 & Interesting \\
\hline 2 & Less attractive \\
\hline 1 & Very less attractive
\end{tabular}

Data that has been collected will be analyzed using the following formula:

$\mathrm{P}=\frac{x}{x i} \times 100 \%$

Keterangan:

$\mathrm{P} \quad=$ Percentage of assessment

$x=$ Respondent's answer in all items

$x_{\mathrm{i}} \quad=$ Maximum score

\section{RESULTS AND DISCUSSION}


Student's responses

Responses in this study are categorized as responses, behaviors, and answers given by students to researchers based on the behavior and learning process carried out by the researcher through a given questionnaire. The very interesting responses given by students to gamification media lead to positive responses, such as comfort in understanding the material, being active in every instruction given, and being compact with other students in solving problems. An interesting response is in the form of responses from respondents such as enthusiasm, there is an interaction between respondents and researchers when the application of gamification media continues. Unattractive responses in the form of respondents who have difficulty understanding instructions, conflicting arguments, and student discomfort during the application process of gamification media. Meanwhile, the response is very unattractive in the form of negative responses, such as reluctance to do the assignment given, and not paying attention to the speaker during implementation.

The response questionnaire was given after the gamification implementation process for affixation mastery was completed, namely at the last meeting. The following shows the responses of students from Thailand after the implementation of gamification.

Tables 2. Response to Gamification Strategy

\begin{tabular}{|c|c|c|c|c|c|c|c|c|c|c|}
\hline \multirow{2}{*}{ No. } & \multirow{2}{*}{$\begin{array}{l}\text { Responded } \\
\text { Statements }\end{array}$} & \multicolumn{4}{|c|}{ Score } & \multirow{2}{*}{ Amount } & \multicolumn{4}{|c|}{ Percentage \% } \\
\hline & & 1 & 2 & 3 & 4 & & 1 & 2 & 3 & 4 \\
\hline 1 & $\begin{array}{l}\text { Do you feel happy } \\
\text { about learning this } \\
\text { gamification } \\
\text { media? }\end{array}$ & - & - & 2 & 24 & 26 & - & - & 7,7 & 92,3 \\
\hline 2 & $\begin{array}{lr}\text { Can } & \text { this } \\
\text { gamification } & \\
\text { increase } & \text { your } \\
\text { enthusiasm } & \text { for } \\
\text { learning? } & \end{array}$ & - & - & - & 26 & 26 & - & - & - & 100 \\
\hline 3 & $\begin{array}{l}\text { Is this Gamification } \\
\text { able to increase } \\
\text { your knowledge } \\
\text { about Indonesian } \\
\text { affixation? }\end{array}$ & - & - & 10 & 16 & 26 & - & - & 38,5 & 61,5 \\
\hline 4 & $\begin{array}{l}\text { Was the speaker } \\
\text { able to deliver it } \\
\text { well? }\end{array}$ & - & - & 5 & 21 & 26 & - & - & 19,2 & 80,8 \\
\hline 5 & $\begin{array}{l}\text { Is this gamification } \\
\text { feasible to be } \\
\text { applied to students }\end{array}$ & - & 6 & 4 & 16 & 26 & - & 23 & $\begin{array}{c}15 \\
3\end{array}$ & 61,5 \\
\hline
\end{tabular}


Based on table 2, it can be seen that the response to statement number 1 , students gave a response of $7.7 \%$ in category 2 , and $92.3 \%$ in category 4 . Category 1 and 2 did not give a response, so it can be concluded that students felt happy with learning gamification media.

The 2 nd statement data shows a response of $100 \%$ in category 4 , no one gives a response to the other categories, thus it can be concluded that gamification media can increase the enthusiasm for learning of Thai students who are studying at Unisda Lamongan.

The 3rd statement gets a response in category 3 of $38.5 \%$, and $61.5 \%$ in category 4, while there is no response for categories 1 and 2 . So it can be concluded that learning with gamification is able to increase the knowledge of Thai students at Unisda Lamongan about Indonesian affixation.

The 4 th statement of respondents gave responses in category 3 of $19.2 \%$ and $80.8 \%$ in category 4 , while categories 1 and 2 did not get responses from students, so it can be concluded that learning with gamification is delivered well by the speakers.

In the 5 th statement, the respondents gave responses in category 2 by $23 \%$, in category 3 it was $15.3 \%$, and in category 4 it was $61.5 \%$, so it can be concluded that gamification media is quite feasible to be applied to students from Thailand at Unisda Lamongan.

\section{Effectiveness of Gamification Media}

Based on the results of observations by researchers on students during the application process of gamification media in cycle I and cycle II, each activity was carried out well and obtained an implementation value of $100 \%$ so that the acquisition of this value could be categorized as very good (Bahri, 2005). The good implementation of this activity cannot be separated from the enthusiasm of students as objects of research to follow the development of learning technology that they have not previously obtained.

The activity of applying gamification media to improve the mastery of Indonesian affixation for Thai students at the Islamic University of Darul 'ulum Lamongan has increased from cycle I to cycle II. The results of this increase are based on the pretest given to determine the number of students' affix managers, namely from 26 student researchers obtained data as many as 226 correct use of words with affixes, and there were 32 incorrect use of affixes. The existence of errors in the use of this affix on average is due to contamination of their foreign language or first language (B1). Then after the application of gamification media in 
the first cycle, the researcher gave a posttest to the students so that the data on the use of Indonesian affixes was obtained as much as 391 correct use of affixes, and 17 incorrect use of affixes. Thus in cycle I there is an additional affix characterization of 165 . Acquisition of affixes during the pretest and posttest can be seen in the following diagram:

Diagram 1. Pretest and posttest of affixation mastery mastery of Thai students at Unisda Lamongan

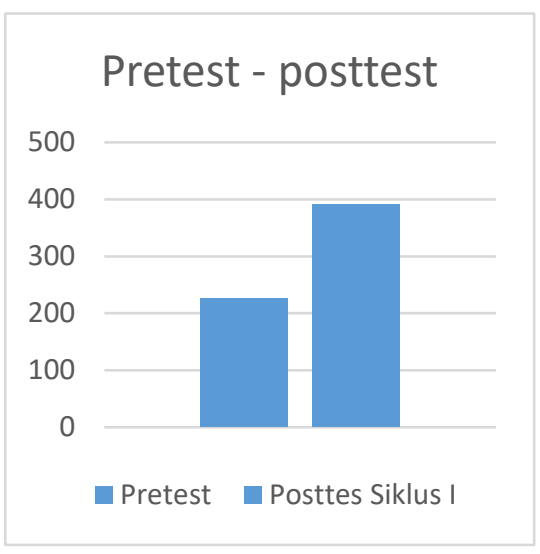

The affixation writing error diagram is as follows:

Diagram 2. Errors Affixation Writing

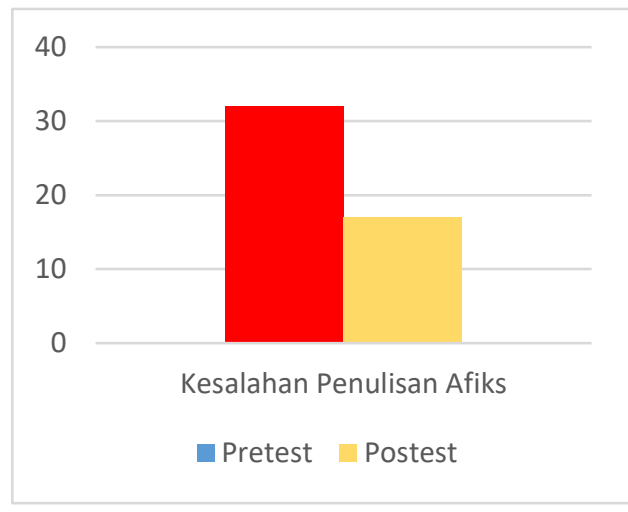

Comparison of the acquisition of Indonesian affixes by Thai students in cycle I and cycle II can be seen in the following diagram.

Diagram 3. Comparison of Cycle I and Cycle II 


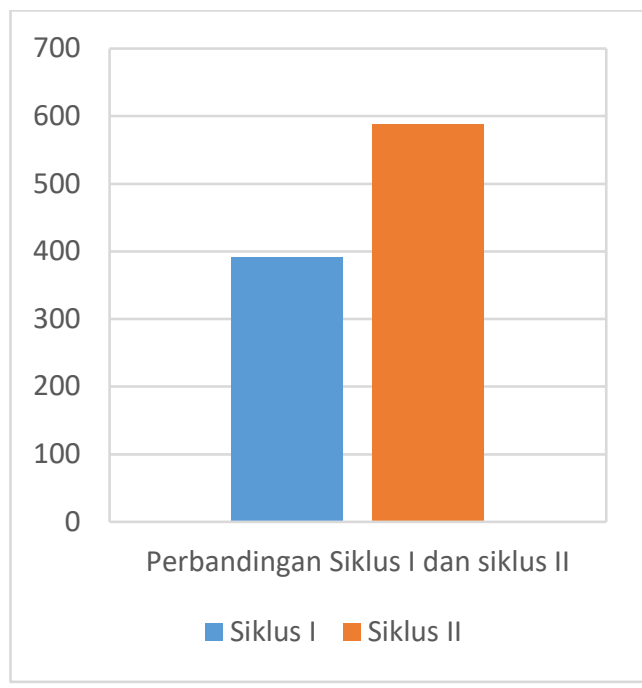

Based on diagram 3, in cycle I the acquisition of Indonesian affixes by Thai students at the Islamic University of Darul 'ulum Lamongan was 391 words, while in cycle II there was an increase of 196 words so that they obtained 587 words with affixes. student from Thailand at the Islamic University of Darul 'ulum Lamongan. Whereas for affix writing errors can be seen in the following diagram:

Diagram 4. Error writing affixes in Cycle I and Cycle II

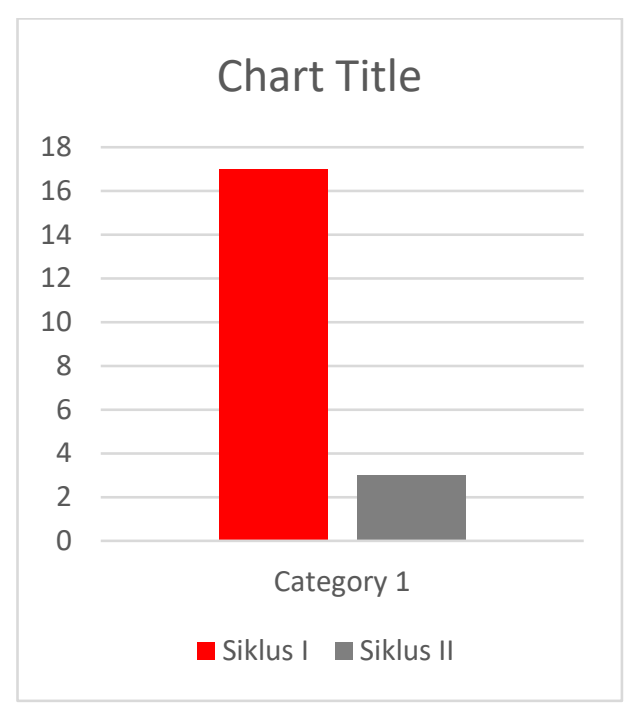

Based on diagram 4, there is a decrease in affix writing errors in Thai students, namely in cycle I there are 17 affix word errors, then in Cycle II, there were 3 errors in writing affixes on affixed words by Thai students. Thus there is a decrease of 14.

\section{CONCLUSION}




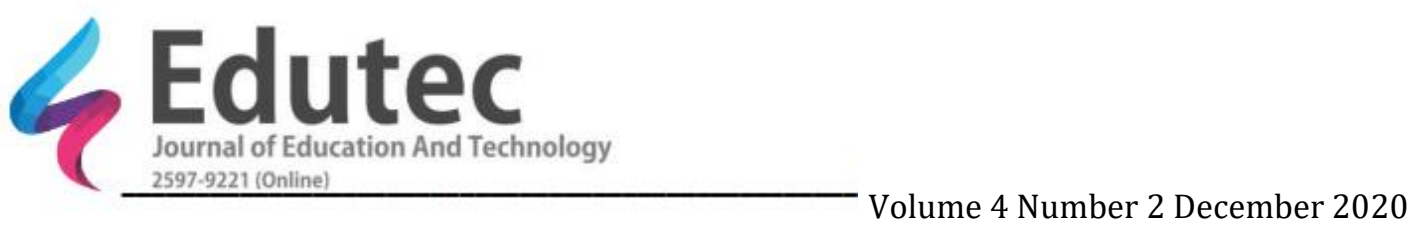

Based on the results of the research and discussion, it can be concluded that the responses of Thai students to gamification media to improve affixation mastery obtained results with very attractive criteria that were much greater in each statement compared to the other categories in each statement. This is based on obtaining the results of a questionnaire from 5 statements, the first statement obtained a very attractive category of $92.3 \%$, the second statement of the very attractive category received a value of $100 \%$, the third statement obtained a respondent's score in the very good category of $61.5 \%$, the fourth statement obtained the response to the very interesting category was $80.8 \%$, and the fifth statement got a response to the very interesting category by $61.5 \%$.

Meanwhile, the effectiveness of the research results showed that the results from cycle I to cycle II had increased. In the pretest stage the researcher obtained data on 226 words with affixes, after implementing the gamification media in the first cycle, 391 words with affixes were obtained, then in the second cycle data were obtained 587 words with an affix, which was an increase of 196 words compared to cycle I.

\section{ACKNOWLEDGMENTS}

The researchers would like to say thank you to the Islamic University of Darul 'ulum (Unisda) Lamongan for providing facilities and support so that researchers can complete research on students from Thailand who are currently studying at the Unisda campus smoothly. We do not forget to say to the Ministry of Research and Technology of the National Research and Innovation Agency (Ristekbrin) who has provided Beginner Lecturer Research (PDP) grants.

\section{REFERENCES}

Amrulloh, M. A. (2017). Analisis Perubahan Morfologis Pembentukan Ta'rib dan Pembelajaran. Tadris: Jurnal Keguruan Dan Ilmu Tarbiyah, 02(2), 87-96. https://doi.org/10.24042/tadris.v2i2.2064

Bahri, D. S. (2005). Guru dan Anak Didikdalam Interaksi Edukatif: Suatu Pendekatan Teoritis Psikologis. PT. Rineka Cipta.

Ihsan, B. (2017). THE ACQUISITION OF INDONESIAN LANGUAGE AFFIXES BY THAI LEARNERS IN ISLAMIC UNIVERSITY DARUL 'ULUM LAMONGAN. Literacy Awareness in Shaping Citizen Character, 177-181.

Sambung, D., Sihkabuden, \& Ulfa, S. (2017). PENGEMBANGAN MOBILE LEARNING BERBASIS GAMIFIKASI UNTUK PENGUASAAN KOSAKATA BAHASA JEPANG KELAS X SMAN 1 GARUM. JINOTEP, 3(2), 121-129.

Tarigan, H. G., \& Tarigan, D. (2011). Pengajaran Analisis Kesalahan berbahasa. 
Angkasa.

Vermana, L., \& Zuzano, F. (2018). Peningkatan Hasil Belajar Persamaan Diferensial Mahasiswa Pendidikan Matematika dengan Model Pembelajaran Flipped Classroom. EDUMATICA / Jurnal Pendidikan Matematika, 8(2), 23-34. https://doi.org/10.22437/edumatica.v8i2.5576

Wastari, D. A. Y., \& Sagoro, E. M. (2018). PENERAPAN MODEL PEMBELAJARAN KOOPERATIF BERBASIS JURNAL PENYESUAIAN PADA SISWA KELAS X AKUNTANSI G SMK MUHAMMADIYAH 1 YOGYAKARTA TAHUN AJARAN IMPLEMENTATION OF GAMIFICATION BASED OORPERATIVE LEARNING TO STUDENTS ' LEARNING OUTCOMES OF ADJUSTING JOURNAL EN. Kajian Pendidikan Akuntansi Indonesia, 7(1), 1-12. 